This article was downloaded by: [University of Alberta]

On: 25 April 2015, At: 17:46

Publisher: Taylor \& Francis

Informa Ltd Registered in England and Wales Registered Number:

1072954 Registered office: Mortimer House, 37-41 Mortimer Street, London W1T 3J H, UK

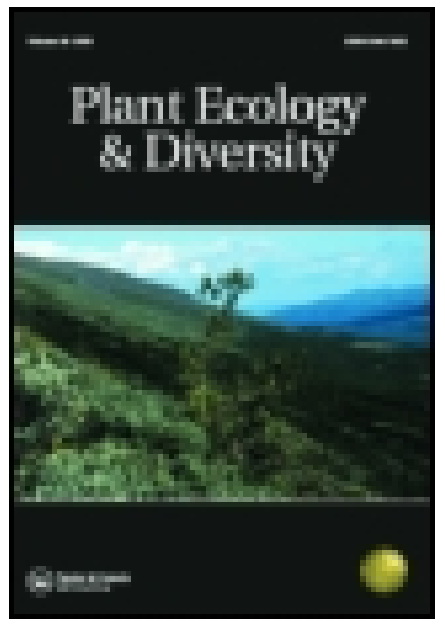

\title{
Transactions of the Botanical Society of Edinburgh
}

Publication details, including instructions for authors and subscription information: http:// www. tandfonline.com/loi/ tped18

\section{Notice of Grimmia contorta of Schimper, a new British Moss}

Professor Dickie

Published online: 01 Dec 2010.

To cite this article: Professor Dickie (1870) II. Notice of Grimmia contorta of Schimper, a new British Moss, Transactions of the Botanical Society of Edinburgh, 10:1-4, 19-20, DOI: 10.1080/03746607009468639

To link to this article: http:// dx. doi. org/ 10.1080/03746607009468639

\section{PLEASE SCROLL DOWN FOR ARTICLE}

Taylor \& Francis makes every effort to ensure the accuracy of all the information (the "Content") contained in the publications on our platform. However, Taylor \& Francis, our agents, and our licensors make no representations or warranties whatsoever as to the accuracy, completeness, or suitability for any purpose of the Content. Any opinions and views expressed in this publication are the opinions and views of the authors, and are not the views of or endorsed by Taylor \& Francis. The accuracy of the Content should not be relied upon and should be independently verified with primary sources of information. Taylor and Francis shall not be liable for any losses, actions, claims, proceedings, demands, costs, expenses, damages, and other liabilities whatsoever or howsoever caused arising directly or indirectly in connection with, in relation to or arising out of the use of the Content. 
This article may be used for research, teaching, and private study purposes. Any substantial or systematic reproduction, redistribution, reselling, loan, sub-licensing, systematic supply, or distribution in any form to anyone is expressly forbidden. Terms \& Conditions of access and use can be found at http://www.tandfonline.com/page/terms-andconditions 
in Britain answering to his description." In examining Hudson's description as given by Smith, I do not find that it corresponds with $H$. collinum.

Hooker and Arnott in their "British Flora" (p. 209) say, "we omit here $H$. dubium, Huds., not L., as it is quite uncertain what plant was intended; the description given by Woodward, in Withering's 'Botanical Arrangement,' and the figure in English Bot. t. 2332, both of garden specimens, belonging to $H$. stoloniferum, W. and K., while Smith's description in the 'English Flora' is taken from $H$. Auricula, L. We also omit $H$. Auricula, L., said to have been found in Westmoreland, the description and figure, Eng. Bot. t. 2368, given by Smith, being taken from a Swiss specimen of $H$. glaciale, Lach."

Explanation of Plate I.; representing Hieracium collinum, Fries, from specimens collected on the banks of the Ettrick, Selkirkshire.-Fig. 1. The plant, natural size. 2. A flower. 3. Bifid termination of a style. 4. A hair of the pappus. Figs. 2, 3, and 4 magnified.

\section{Notice of Grimmia contorta of Schimper, a New British Moss. By Professor Dickie.}

This moss was discovered for the first time in Britain by $\mathrm{Mr}$ John Sim, Gateside, Strachan, growing in considerable abundance on the exposed south and west sides of the great granite rock of Clochnaben, Kincardineshire, in June 1868.* It is the Dicranum contortum of Wahl., and Grimmia uncinata of Kaulf., Bryo. Europ., vol. iii. t. 248. The following description of the species is from Schimper's "Synopsis Muscorum Europæorum," p. 209 :-

"Cæspitulosa, cæspituli molles saturate virides inferne nigricantes et eximie discolores, stupa radiculosa basilari cohærentes. Folia patenti-incurva, sicca crispula, e lanceolato lineali-subulata, apice diaphana vel brevipila, basi carinato-concava margine recurva, dehine subcornplicato-carinata, sola juniora viridia, cætera nigricantia vel fuscescentia; rete e cellulis formatum majoribus, apice sinuoso-quadratis basi elongatis hexagono-rectangulis diaphanis. Perichætium 8-9-phyllum, longe productum, folia peri-

* This moss had been previonsly gathered on the Cheviots in May 1868 by Mr James Hardy._J. H. B. 
chætialia erecta basi longius vaginantia pallidiora. Capsula in pedicello subarcuato cernua siccitate erecta, ovalis, lævis, mollis, lutescens, respectu magnitudinus plantæ parvula. Operculum convexo-conicum, obtusum, basi erosum, aurantio-rubens. Annulus latus, e triplici serie cellularum compositus. Peristomii dentes infra medium usque bifidi et lacunosi, siccitate reflexi, aurantio-rufi."

III. Extracts from Botanical Correspondence. By Professor BALFOUR.

1. From Mr R. Shuttleworth, Berne, giving an account of the botany of the Var and of the Alpes Maritimes, and part of Liguria, a Flora of which he is preparing for publication.

2. From Professor Dickie, noticing the naturalisation of Lupinus perennis in Deeside. It has been knowu for many years growing in the woods at Balmoral, doubtless an outcast from the old garden. It has spread downwards along the course of the Dee, and occurs in great abundance on a small island a little west from the bridge at Ballater, and on another about a mile west from the old bridge of Dee at Aberdeen.

3. From Mr Gilbert C. A. Stuart, giving a list of the plants which he had found naturalised on the banks of the 'T'weed and Gala,-the seeds having been introduced by the wool brought to the Galashiels factories. They included Herniaria ciliata, Illecebrum verticillatum, Lythrum hyssopifolium, Medicago denticulata, $M$. maculata, $M$. minima, Apera Spica-venti, Setaria viridis, \&c.

4. $\mathrm{Mr}$ Archibald Jerdon, transmitting specimens of Polycarpon tetraphyllum and Medicago denticulata, which he had collected near Melrose.

5. From Mr J. F. Robinson, giving a list of the Ferns found in the neighbourhood of Frodsham, Cheshire.

6. From Mr P. S. Robertson and Mr Henderson, presenting specimens of Potato tubers exhibiting the second growth where numerous tubers are produced from a parent tuber. The specimens were from the gardens of Mr Mowat, Trinity, and Mr Henderson, Burntisland.

Professor Dickson gave a demonstration on the hard 